\begin{tabular}{|l|l|l||}
\hline \multicolumn{2}{|c|}{ PublisherInfo } \\
\hline \hline PublisherName & $:$ & BioMed Central \\
\hline \hline PublisherLocation & $:$ & London \\
\hline \hline PublisherImprintName & $:$ & BioMed Central \\
\hline \hline
\end{tabular}

\title{
Deficiency of Il-1ra may predispose to development of arthritis
}

\begin{tabular}{|l|l|l||}
\hline \multicolumn{2}{|c|}{ ArticleInfo } \\
\hline \hline ArticleID & $:$ & 193 \\
\hline \hline ArticleDOI & $:$ & $10.1186 /$ ar-2000-66798 \\
\hline \hline ArticleCitationID & $:$ & 66798 \\
\hline \hline ArticleSequenceNumber & $:$ & 150 \\
\hline \hline ArticleCategory & $:$ & Paper Report \\
\hline \hline ArticleFirstPage & $:$ & 1 \\
\hline \hline ArticleLastPage & $:$ & 3 \\
\hline \hline & & RegistrationDate : 2000-4-10 \\
\hline ArticleHistory & $:$ & OnlineDate \\
\hline \hline ArticleCopyright & $:$ & Current Science Ltd2000-4-10 \\
\hline \hline ArticleGrants & $:$ & \\
\hline \hline ArticleContext & $:$ & 130753311 \\
\hline \hline
\end{tabular}


Affl St Vincent's University Hospital, Dublin

\section{Keywords}

IL-1ra gene deficiency, mouse model, rheumatoid arthritis

\section{Context}

Rheumatoid arthritis (RA) is a chronic systemic disease which commonly results in joint damage and consequent disability. Various pro-inflammatory cytokines such as IL-1, IL-6 and tumor necrosis factor (TNF)-a are overexpressed in the joints of RA patients. IL-1 is thought to be a major mediator of inflammation as it exerts a number of biological activities by binding the IL-1 type I receptor. IL-1 ra is a naturally occurring inhibitor of IL-1 which competes for the receptor. Previous studies have suggested that IL-1ra production may be relatively deficient or inadequate in RA patients. IL-1ra gene polymorphism has not, as yet, been reported in RA in humans. To study the pathophysiological roles of IL-1ra in regulating the inflammatory response.

\section{Significant findings}

IL-1ra-deficient mice on a BALB/cA background all developed a chronic inflammatory arthropathy by 16 weeks. In contrast, none of the IL-1 ra-deficient mice on a C57BL/6J background developed any arthritis at 16 weeks of age. In mice developing arthritis, both the incidence and severity gradually increased to a maximum at 16 weeks. Marked synovial and periarticular inflammation was observed with articular erosion resulting from invasion of granulation tissue. These findings are similar to those of RA in humans. T-cell and B-cell composition in lymphoid tissue was not altered by IL-1ra deficiency. Total IgG and IgE levels were elevated two- to threefold at 16 weeks in mice with arthritis. In addition, there was a significant elevation in antibody levels against $\operatorname{IgG}$, type II collagen and double-stranded DNA. Finally, the IL-1? mRNA level was increased tenfold in arthritic joints at 16 weeks compared to that for controls and expression levels of IL-6, TNF-a and COX-2 were also augmented. Interestingly, the augmentation of these genes was observed in joints before the onset of clinical disease.

\section{Comments}


The etiopathogenesis of rheumatoid arthritis (RA) has not been elucidated completely. In this study, the authors describe the histological features, autoantibody profiles, and cytokine expression in interleukin 1 receptor antagonist (IL-1ra) deficient mice backcrossed on a BALB/cA background. All of these mice spontaneously develop a chronic inflammatory arthropathy that closely resembles RA. Overall, these results suggest that IL-1ra deficiency results in a chronic arthritis, raising the intriguing possibility that a similar gene deficiency may play

a role in RA in humans. While of interest, additional experiments are required to examine the role of bacterial flora in disease and to examine which additional genes in the BALB/cA mice are contributing to disease expression.

\section{Methods}

IL-1ra-deficient mice were produced by gene targeting. The mice were then backcrossed to several lines of inbred mice of different genetic backgrounds to see the difference in inflammatory reactions amongst strains. The histological features, autoantibody production and synovial cytokine expression were determined.

\section{References}

1. Horai R, Saijo S, Tanioka H, Nakae S, Sudo K, Okahara A, Ikuse T, Asano M, Iwakura Y: Development of chronic inflammatory arthropathy resembling rheumatoid arthritis in interleukin 1 receptor antagonist-deficient mice. J Exp Med. 2000, 191: 313-320.

This PDF file was created after publication. 